ISSN 0258-7122

Bangladesh J. Agril. Res. 36(3): 369-380, September 2011

\title{
ASSESSMENT OF NUTRITIVE VALUE IN MILLED RICE GRAIN OF SOME INDIAN RICE LANDRACES AND THEIR MOLECULAR CHARACTERIZATION
}

\author{
S. BANERJEE ${ }^{1}$, G. CHANDEL ${ }^{2}$, N. MANDAL $^{1}$ \\ B. M. MEENA ${ }^{2}$ AND T. SALUJA ${ }^{2}$
}

\begin{abstract}
The study was aimed at the evaluation of nutritive values in terms of total protein and some essential amino acid content of a set of 258 diverse rice landraces maintained in the Germplasm Section of Indira Gandhi Agricultural University at Raipur, Chhattisgarh. Protein content of milled grains ranged from $4.91 \%$ to $12.08 \%$ with the mean of $6.63 \%$. Similarly wide variation was recorded in lysine content which varied from 1.73 to $7.13 \mathrm{~g} / \mathrm{l6g} \mathrm{N}$, the mean being $4.62 \mathrm{~g} / \mathrm{I} 6 \mathrm{~g} \mathrm{~N}$. Grain protein and lysine levels varied two to three folds. Variation for lysine content (CV 23.68\%) was higher than that of protein content (CV 12.45\%). This clearly indicated the existence of wide genetic variability for protein and lysine contents in rice. Two sets of ten elite lines each containing high levels of protein and lysine were further analyzed separately for another essential amino acid tryptophan. In the set with high protein, the tryptophan levels varied from $0.36-0.88 \mathrm{~g} / 16 \mathrm{~g} \mathrm{~N}$, the mean being $0.642 \mathrm{~g} / 16 \mathrm{~g} \mathrm{~N}$. Among the landraces containing high levels of lysine, the tryptophan content ranged from 0.256 to $0.86 \mathrm{~g} / 16 \mathrm{~g} \mathrm{~N}$, the average being 0.514 . A positive correlation of tryptophan with lysine content $(\mathrm{r}=0.076)$ and a strong negative correlation with total protein content $(\mathrm{r}=-\mathbf{0 . 9 2 3 )}$ were recorded. Donor lines for breeding rice varieties with optimum protein quality were identified as potential donor parents for genetic improvement of rice for nutritious grains. Fourteen SSR primer sets were used to investigate the level of polymorphism among the ten elite landraces of extra early maturity group. The estimated similarity ranged from 20.18 to 69.00\% reflecting much variation at the DNA level.
\end{abstract}

Keywords: Milled rice grain, protein, lysine, tryptophan, nutritive value of rice.

\section{Introduction}

The nutritional status of population of the developing world is affected by several factors including population density and rate of growth, the ability of the population to grow or buy enough staples for its own use, and economies of scale in agricultural research that decrease the diversity of the food supply. Among cereals, rice is the staple food for more than half of the world's population. It has shaped the cultures, diets, and economies of billions of people. In fact, rice is the most important crop for the people living in Asia where it has a long history of

${ }^{1}$ Department of Biotechnology, Bidhan Chandra Krishi Vishwavidhyalaya, West Bengal, India, ${ }^{2}$ Department of Biotechnology, IGKV, Raipur, Chhattisgarh, India. 
cultivation and is deeply ingrained in the daily lives of Asian people (Narayanan et al., 2000). Under nutrition is one of the most significant factors facing the developing world. Only twenty percent of the world people are affluent enough to have access to nutritious diet. Protein energy malnutrition (basic hunger or under nutrition) affects 850 million people worldwide. It is estimated that under nutrition is the cause of half of all the cases of child mortality. In India, over 50\% of all children receive insufficient calories everyday to meet their potential growth and development requirements (Mahendra et al., 2004). Indeed, about eighty per cent of all malnourished children in the developing world live in countries that boasted food surpluses. With more than seventy per cent of the world's malnourished children, Sub-Saharan Africa, and South Asia are expected to remain "Black Spots" of child malnutrition in 2020. A substantial decrease in the availability of legumes over three decades, from an average of $64.4 \mathrm{~g}$ during the pre-Green Revolution decade to about 33.6g per capita per day during 1996 to 2002 in our country has been largely responsible for protein malnutrition. Moreover, the quality of a protein is always determined by its amino acid profile. Studies conducted in the 1950s and 1960s on children recovering from proteinenergy malnutrition demonstrated that essential amino acids like lysine and tryptophan were important in improving nitrogen retention when cereals like wheat, rice or corn was the staple food (Pellett and Ghosh, 2004). Nowadays, the rice grain is usually further processed by additionally removing the bran layer from the endosperm to obtain milled rice. This implies not only the loss of a nutritionally valuable rice component in human diets but also a reduction of the quantity of rice available for human nutrition by around 10 to 15 percent. In rice, polishing removes $15 \%$ of the protein and also results in a significant loss of other nutrients.

Rice has one of the largest ex-situ germplasm collections of the world (Jackson and Juggan, 1993). The large germplasm of rice includes many land races and related wild species. India is a major center of diversity, notably the mid-eastern part (Chhattisgarh region) and the North-eastern hills. This biodiversity provides further genetic improvement of plant foods for high protein and micronutrients (Khush, 2002). Therefore, developing nutritionally enriched staple plant foods either through plant breeding methods or via molecular biological techniques holds a great promise for sustainable food based solutions (Banziger and Long, 2000; Graham et al., 2001). Therefore, nutritive assessment of the variability in the available rice germplasm and their further utilization in the breeding programme is the need of the today towards the 'hidden hunger' free world. 


\section{Materials and Method}

\section{Genetic materials}

The materials included in the present study consisted of two fifty eight rice landraces of CG Gene Bank, categorized under extra early group (up to 95 days). A selected set of elite genotypes were also analyzed for the protein content and essential amino acids content across two environments during kharf 2005 and rabi (winter season) 2006-07.

\section{Field design}

The rice genotypes were planted in a randomized complete block design (RCBD) with two replications per entry. Standard agronomic practices were followed for raising and maintenance of plants. The single plant harvests of grown plants were procured.

\section{Dehusking polishing and grinding}

Before analyzing the rice samples for various nutritional characters, the seeds of all the 258 accessions were subjected to dehusking, polishing, and grinding. The rice grains were polished to achieve commercial level of whiteness as standardized by Chandel et al. (2005) at Nutritional Quality Laboratory, IGAU, Raipur. The commercial level of whiteness (36 to $45 \%$ diffused reflectance) was reached with $2.0 \mathrm{~mm}$ of polishing in rice accessions with brown pericarp and 3.0 $\mathrm{mm}$ polishing with red pericarp rice accessions. Polishing has been done using Kett Electrical polishing unit with rubber roller. The whiteness of polished rice grains was recorded by reflectance meter prior to making powder for analysis. Rice grain of all the accessions were powdered using pestle mortar.

\section{Estimation of protein}

Total protein of polished rice grains of 258 rice accessions was estimated by modified Microkjeldahl method given by John et al. (2000) for rice grains.

\section{Estimation of lysine}

Lysine content of polished grains was estimated by using spectrophotometer based method (John et al., 2000). Absorbance of aqueous layer was measured at $390 \mathrm{~nm}$. Prepared standard curve (Fig. 3.3) was used to determine the lysine composition of the samples. The following formula was used for the estimation of lysine and amount of lysine in the sample was expressed as g per $16 \mathrm{~g} \mathrm{~N}$.

Amount of lysine $(\mathrm{g} / 16 \mathrm{~g} \mathrm{~N})=\frac{\text { Lysine value from graph in } \mu \mathrm{g} \times 0.16}{\text { Percent } \mathrm{N} \text { in the sample }}$ 


\section{Preparation of standard graph for lysine estimation}

Serial dilution of lysine monohydrochloride (40, 80, 120, 160, and $200 \mu \mathrm{g})$ were prepared and used for the preparation of standard curve. Standard graph obtained for Lysine estimation by using Lysine monohydrochloride

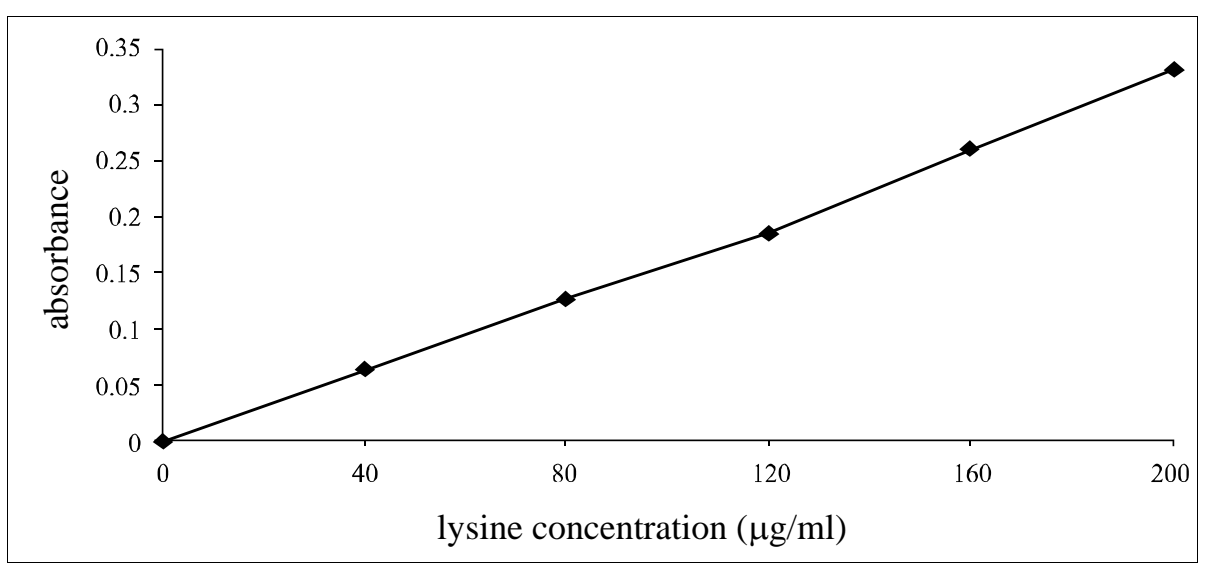

Figure 1.0

\section{Estimation of tryptophan}

Tryptophan content of polished grains was estimated by using spectrophotometer based method (John et al., 2000). A blue colour was developed and absorbance of the coloured solution was measured at $660 \mathrm{~nm}$. Prepared standard curve was used to determine the tryptophan composition of the samples. The following formula was used for the estimation of tryptophan and amount of tryptophan in the sample was expressed as g per $16 \mathrm{~g} \mathrm{~N}$.

Tryptophan in grain sample $(\mathrm{g} / 16 \mathrm{~g} \mathrm{~N})=\frac{\text { Tryptophan value from graph in } \mu \mathrm{g} \times 0.096}{\text { Percent nitrogen in the sample }}$

\section{Statistical analysis}

The observations were recorded for nutritionally important characters, total protein, lysine, tryptophan (essential amino acids), K-Means Cluster Analysis of rice landraces was done for identification of potential donor rice accessions for breeding nutritious rice cultivars. Further molecular characterization of the elite landraces was done with using SSR markers.

\section{Genomic DNA isolation}

Approximately 20 seeds often elite rice landraces identified for high protein content were sown in Petri plates and kept in $\mathrm{BDO}$ incubator at $30^{\circ} \mathrm{C}$. The 7 days 
old shoots tissues were harvested in liquid nitrogen and used for DNA isolation. The genomic DNA was isolated by Dellaporta method (Dellaporta et al., 1983).

\section{DNA amplification by PCR and electrophoresis}

PCR reactions were performed on each DNA sample in a $25 \mu 1$ reaction mix containing $2.0 \mu \mathrm{l}$ of $10 \mathrm{x}$ Taq Polymerase buffer, I $\mu \mathrm{l}$ of forward primer and I ul of reverse primer, $2.0 \mu \mathrm{l}$ of dNTPs, $0.2 \mu \mathrm{l}$ of AmpliTaq DNA polymerase, and $2.0 \mu \mathrm{l}$ of genomic DNA and $11.0 \mu \mathrm{l}$ of sterile deionized water. DNA amplification was performed in a PTC 100 (Programmable Thermal Cycler) of Mj Research Pvt. Ltd., USA. The reaction mix was preheated at $94^{\circ} \mathrm{C}$ for $3 \mathrm{~min}$ followed by 40 cycles of 1 minute denaturation at $94^{\circ} \mathrm{C}, 1 \mathrm{~min}$ annealing at $55^{\circ} \mathrm{C}$ and extension at $72^{\circ} \mathrm{C}$ for 2 min. After the last cycle, a final extension step of $7 \mathrm{~min}$ at $72^{\circ} \mathrm{C}$ was added to allow complete extension of all the amplified fragments.

\section{Results and Discussion}

\section{Grain protein and lysine content}

Protein content of milled grain among the two fifty eight rice lines ranged from $4.91 \%-12.08 \%$ with the mean of $6.63 \%$. Out of total 258 lines analyzed, fifty two were found with $<6.0 \%$ protein, two hundred two landraces were found to possess protein levels between 6.0 - 9.0\% whereas, four lines were found with $>9.0 \%$ of grain protein (Fig. 1.1). Similarly wide variations for lysine content of milled rice grains were recorded. The lysine concentration varied from 1.73 to $7.13 \mathrm{gm} / \mathrm{l6gm} \mathrm{N}$ with the over all mean value of $4.62 \mathrm{~g} / \mathrm{l} 6 \mathrm{~g} \mathrm{~N}$. Out of total 258 accessions analyzed, sixteen accessions posses $<3.0 \mathrm{~g} / 16 \mathrm{~g} \mathrm{~N}$, two hundred fifteen accessions fall within the range of 3.0-6.0 g/16g N, whereas 27 accessions with $>6.0 \mathrm{~g} / \mathrm{l6g} \mathrm{N}$ (Fig.l.2). Two to three fold variation in grain protein and lysine levels were recorded among the rice landraces analyzed in this study. Variation for lysine content (CV 23.68\%) was found to be higher than that of variation for protein content (CV 12.45\%). This clearly indicates the existence of wide genetic variability for protein and lysine contents in rice. Similarly, Riza et al. (2003) showed $6.3 \%$ - $9.1 \%$ grain proteins levels in 438 rice cultivars. Our results are in conformity with the findings of Chandel et al. (2005). They reported 5.0 to $9.5 \%$ variation for protein and 3.0 to $6.5 \mathrm{~g} / 16 \mathrm{gN}$ for lysine concentrations in milled grains of rice germplasm lines of CG Core collections. 
Figure 1.1

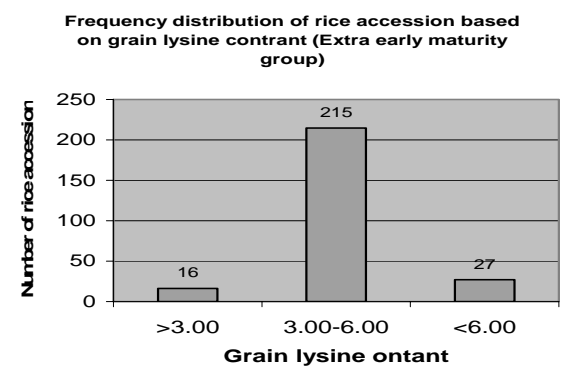

Figure 1.2

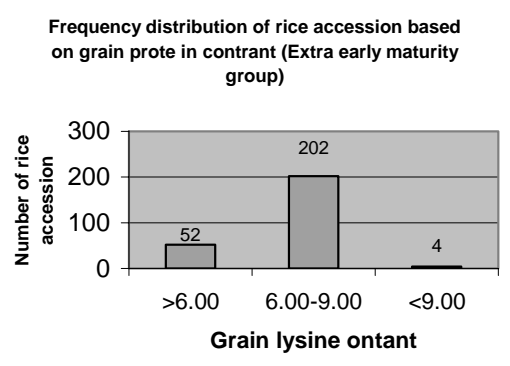

\section{Grain protein and tryptophan content}

A set of ten elite rice lines each containing high levels of protein and lysine, respectively, were further analyzed for another essential amino acid tryptophan. Among the landraces containing high levels of lysine, the tryptophan content ranged from 0.256 to $0.86 \mathrm{~g} / 16 \mathrm{~g} \mathrm{~N}$ with an overall mean value of $0.514 \mathrm{~g} / \mathrm{I} 6 \mathrm{~g} \mathrm{~N}$. Whereas, in rice landraces with high grain protein, the tryptophan levels were found to vary from $0.36-0.88 \mathrm{~g} / \mathrm{I} 6 \mathrm{~g} \mathrm{~N}$ with an overall mean of $0.642 \mathrm{~g} / 16 \mathrm{~g} \mathrm{~N}$ ).

\section{Correlation studies between essential amino acids (Lysine and Tryptophan) and protein}

A positive correlation of tryptophan with lysine contents $(\mathrm{r}=0.076)$ and a strong negative correlations with total protein contents $(r=-0.923)$ in rice were recorded among the rice landraces used in this study as shown in Fig 2.1 and Fig 2.2 respectively. This suggests that breeding effort for increasing lysine content can also lead to increase in tryptophan content in rice grains.

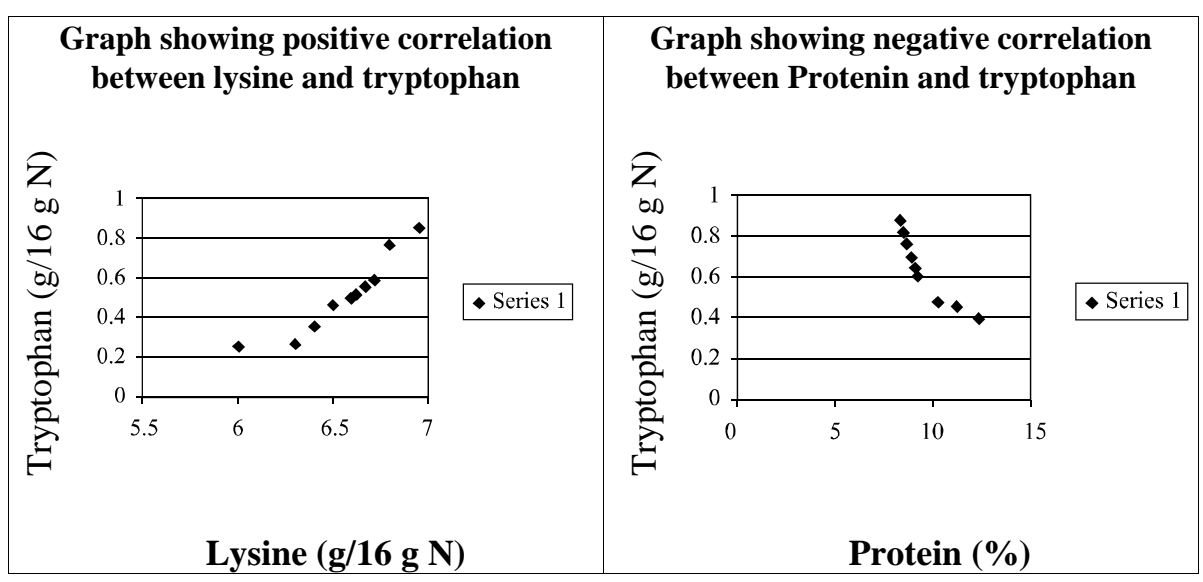


On the basis of single point data generated from the screening studies, five landraces of rice with $>9.5 \%$ grain protein (Table 1.1) and five landraces with > $6.0 \mathrm{~g} \mathrm{~N} / 16 \mathrm{~g} \mathrm{~N}$ lysine concentrations (Table 1.2) were identified and analyzed two times to confirm the results

Table 1.1 Mean protein contents of top five rice accessions.

\begin{tabular}{|c|c|c|c|c|}
\hline \multirow{2}{*}{ Name of accession } & \multirow{2}{*}{ Collection site } & \multicolumn{3}{|c|}{ Endospermic level of protein (\%) } \\
\hline & & $\mathrm{R}_{1}$ & $\mathrm{R}_{2}$ & Mean* \\
\hline Harad Gundi & Raigarh & 10.03 & 9.83 & 9.93 \\
\hline Koliha chheriha & Raipur & 10.93 & 9.83 & 10.38 \\
\hline Hardeshi & Mandsaur & 12.08 & 8.69 & 10.38 \\
\hline Dudhiya danwar & Bastar & 8.36 & 8.72 & 8.54 \\
\hline Gudma dhan & Bastar & 8.26 & 9.13 & 8.69 \\
\hline
\end{tabular}

*Commercial level of whiteness 38-42\%

Table 1.2 Mean lysine contents of top five rice accessions.

\begin{tabular}{|c|c|c|c|c|}
\hline \multirow[t]{2}{*}{ Name of accessions } & \multirow{2}{*}{$\begin{array}{l}\text { Collection } \\
\text { sites }\end{array}$} & \multicolumn{3}{|c|}{$\begin{array}{l}\text { Lysine concentration in polished grains } \\
\qquad(\mathrm{g} / \mathrm{I} 6 \mathrm{~g} \mathrm{~N})\end{array}$} \\
\hline & & $\mathrm{R}_{1}$ & $\mathrm{R}_{2}$ & Mean* \\
\hline Chhote sathaka & Bastar & 6.00 & 6.59 & 6.30 \\
\hline Pinnabasengi & Bastar & 6.30 & 6.21 & 6.25 \\
\hline Chhota kabari & Bastar & 6.80 & 7.46 & 7.13 \\
\hline Tikrajhilli & Raigarh & 6.67 & 6.53 & 6.60 \\
\hline Bhata khuji & Bastar & 6.40 & 6.87 & 6.63 \\
\hline
\end{tabular}

*Commercial level of whiteness 38-42\%

Table 1.3 Mean tryptophan contents of top five rice accessions.

\begin{tabular}{|c|c|c|c|c|}
\hline \multirow[t]{2}{*}{ Name of accessions } & \multirow{2}{*}{$\begin{array}{l}\text { Collection } \\
\text { site }\end{array}$} & \multicolumn{3}{|c|}{$\begin{array}{l}\text { Tryptophan concentration in polished grains } \\
\qquad(\mathrm{g} / \mathrm{l6g} \mathrm{N})\end{array}$} \\
\hline & & $\mathrm{R}_{1}$ & $\mathrm{R}_{2}$ & Mean* \\
\hline Gudma & Bastar & 0.89 & 0.87 & 0.88 \\
\hline Gudmadhan & Bastar & 0.87 & 0.85 & 0.86 \\
\hline Dudhiyadanwar & Bastar & 0.80 & 0.82 & 0.81 \\
\hline Chhote Sathaka & Bastar & 0.75 & 0.76 & 0.77 \\
\hline CR-126-33-1 1 & Raipur & 0.85 & 0.86 & 0.85 \\
\hline
\end{tabular}

\section{Cluster Analysis of rice landraces for identification of potential donors}

On the basis of K-Means Cluster analysis, 258 rice landraces were grouped into ten clusters. The cluster IV consisted of maximum number of 36 rice landraces. 
Cluster VIII consisted of minimum number of 19 landraces. Each of clusters I, II, and VI consisted of 22 landraces. Cluster IV was followed by cluster III containing 31 landraces, then by cluster VIII containing 30 landraces. Cluster V, IX, and X consisted of 28, 27, and 21 landraces, respectively .The genetic divergence among the clusters is reflected in the cluster means as shown in Table 2.1. The cluster mean values showed wide differences for all the three characters studied. Cluster IX showed highest value for protein content (7.20\%). Cluster II have highest mean values for lysine content $(4.87 \mathrm{~g} / 16 \mathrm{~g} \mathrm{~N})$ and the highest mean value for grain tryptophan content $(0.88 \mathrm{~g} / 16 \mathrm{~g} \mathrm{~N})$. Cluster II have second highest value for protein content

Table 2.1 Cluster mean of three nutritionally important traits of rice landraces of extra-early maturity group.

\begin{tabular}{l|c|c|c}
\hline $\begin{array}{c}\text { Cluster } \\
\text { no. }\end{array}$ & $\begin{array}{c}\text { Protein } \\
(\%)\end{array}$ & $\begin{array}{c}\text { Lysine } \\
(\mathrm{g} / 16 \mathrm{~g} \mathrm{~N})\end{array}$ & $\begin{array}{c}\text { Tryptophan } \\
(\mathrm{g} / 16 \mathrm{~g})\end{array}$ \\
\hline I & 6.527 & 4.556 & 0.55 \\
II & 6.882 & 4.877 & 0.88 \\
III & 6.673 & 4.449 & 0.77 \\
IV & 6.514 & 4.706 & 0.81 \\
V & 6.792 & 4.461 & 0.58 \\
VI & 6.329 & 4.605 & 0.76 \\
VII & 6.443 & 3.863 & 0.85 \\
VIII & 6.861 & 4.679 & 0.59 \\
IX & 7.202 & 4.462 & 0.84 \\
X & 6.817 & 4.625 & 0.68 \\
\hline
\end{tabular}

Basis of selection of donor lines

The greater the distance between two clusters, the wider the genetic diversity between their genotypes. However, while considering genetic diversity among the parents to be included in any breeding programme parents/donor lines combining high yield potential with wide genetic diversity are likely to yield superior segregates within a short period. Based on these facts, rice landraces (Haradgundi), (Hardeshi) from cluster IX and (Katuli) from cluster VI can be used as donor lines for breeding rice rich in endospermic protein. For breeding rice with good protein quality, cluster II seemed to be the most promising as it exhibited relatively higher mean values for both protein (6.88\%), tryptophan content $(0.88 \mathrm{~g} / \mathrm{l} 6 \mathrm{~g} \mathrm{~N})$ and lysine content $(4.87 \mathrm{~g} / \mathrm{I} 6 \mathrm{~g} \mathrm{~N})$. Identified donor lines are shown in Table 2.2. 
Table 2.2 Donor lines identified for optimum protein quality among extra-early rice landraces:

\begin{tabular}{l|l|l|l|l}
\hline $\begin{array}{c}\text { SL } \\
\text { No. }\end{array}$ & \multicolumn{1}{c|}{ Name } & Protein (\%) & Lysine (g/I 6g N) & Tryptophan (g/l6g N) \\
\hline 1 & Tikra jhilli & 6.16 & 6.67 & 0.55 \\
2 & Chhote sathaka & 6.87 & 6.59 & 0.77 \\
3 & CR-126-33-I 1 & 6.64 & 6.95 & 0.86 \\
4 & Dulari & 7.15 & 6.71 & 0.59 \\
\hline
\end{tabular}

Polymorphic loci detected by SSR markers among the High protein and lysine rice lines.

1. Chhote sataka 2. Pinna basengi 3. Chhota kabari 4. Tikra Jhilli 5. Bhata khuji 6. Koliha chheriha 7. Gudma dhan 8. Dudhiya danwar 9. Harad gundi 10. Hardeshi

\section{DNA fingerprinting of elite rice lines using SSR marker}

Fourteen SSR primer sets were used to investigate the level of polymorphism among the ten elite rice landraces of extra early maturity group, five each for high grain protein (more than 9.0\%) and lysine contents (more than $6.0 \mathrm{~g} / 16 \mathrm{~g}$. $\mathrm{N})$. The bands observed as shown in Fig. 2.3 were recorded as 0 or I for absent or present and recorded as $\mathrm{A}, \mathrm{B}, \mathrm{C}$ depending upon their molecular weight in descending order for each set of micro satellite primer. The total numbers of alleles amplified in the set of ten elite rice lines at twenty different loci were forty-six with and 4 average number of 2.30 alleles per locus. Similarly Jam et al. (2004) evaluated 24 rice genotypes using SSR primers; a high level of polymorphism among the different rice genotypes was found. A total of 229 alleles were detected with an average no. of 4.58 per locus. In an attempt to characterize, Tarori Basmati, Evolved Basmati, and New Basmati Nagaraju et al. (2002) reported the amplification of total 70 alleles across 24 rice varieties by using 19 microsatellite markers. The number of alleles ranged from 2 to 8 with an average of 3.8 alleles as shown in Table 2.3.

Table 2.3 Summarized number of alleles detected across ten rice accessions.

\begin{tabular}{l|l|l|l|l|l}
\hline \multicolumn{1}{c|}{ S. No. } & \multicolumn{1}{c|}{ Primer } & $\begin{array}{c}\text { Number of } \\
\text { alleles }\end{array}$ & S. No. & Primer & $\begin{array}{c}\text { Number of } \\
\text { alleles }\end{array}$ \\
\hline I & RM 144 & 2 & 8 & RM 178 & 2 \\
2 & RM 138 & 1 & 9 & RM I2I & 3 \\
3 & RM 104 & 2 & 10 & RM 83 & 3 \\
4 & RM 130 & 2 & 11 & RM 339 & 2 \\
5 & RM 313 & 2 & 12 & RM 30 & 3 \\
6 & RM 2I & 4 & 13 & RM 17 & 3 \\
7 & RM 256 & 3 & 14 & RM 25 & 2 \\
\hline
\end{tabular}

No specific allele detected for characterizing any of the rice lines analyzed by fourteen SSR primer sets. 

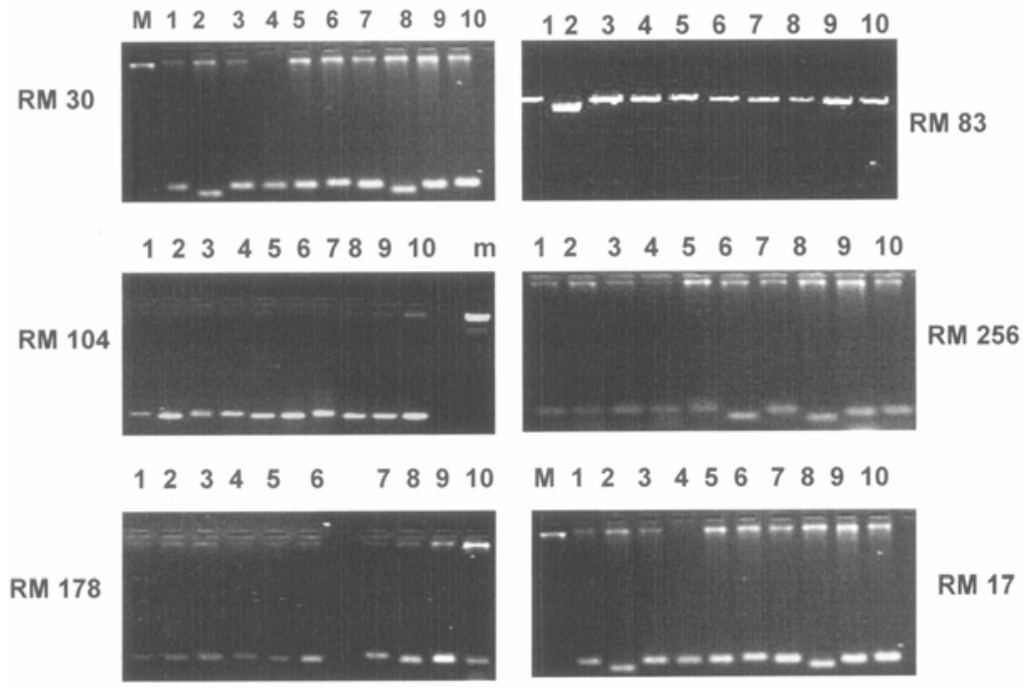

Figure 2.3

\section{Genetic similarity analysis}

Scoring of the bands produced by the amplified products was done designating 1 , 2, 3, and 4 to bands A, B, C, D, respectively, for all the accessions included in this study. Similarity indices were calculated using NTSYS-PC and dendrogram was generated by SAHN subroutine clustering Jaucard coefficient and presented in Fig. 2.3. The estimated similarity ranged from $20.18 \%$ to $69.00 \%$ reflecting that rice landraces shows much variation at DNA level. The highest similarity of 69.00\% was found between landraces Pinna basengi and Chhota kabari. All landraces used in this study were grouped into two major clusters A and B, cluster A consists of four landraces whereas cluster B has six landraces under it. The major cluster A and B were formed at 0.34 similarity level (Fig 2.4). Major cluster A showed sub clustering near 0.63 similarity level, the two sub cluster $A_{1}$ and $A_{2}$ contained of three and one landraces, respectively. The sub cluster $A_{1}$ consists of two groups Chhote sathaka, Pinna basengi, and Chhota kabari in the first group and the sub cluster $A_{2}$ consisted of one line Tikra Jhilli. The second major cluster $\mathrm{B}$ showed sub clustering near 0.46 similarity level, the two sub cluster $B_{1}$ and $B_{2}$ consisted of four and two landraces respectively. The sub cluster $\mathrm{B}_{1}$ consisted of two groups Bhata khuji and Harad Gundi in first group and Koliha chheriha and Hardeshi Boche in second group, the sub cluster $B_{2}$ consisted of two landraces Dudhiya and Gudma danwar.

Similarly Saker et al. (2005) reported similarities among the seven rice varieties ranging from 30.8 to $90.0 \%$ between Giza 177 and Sakha 102 and between Giza 171 
and Sakha 102, respectively. Use of SSR based similarity analysis to estimate the genetic distance between cultivars has been reported in several crops viz, rice (Nagaraju et al., 2002) and rapeseed mustrn (Cuad, et al., 2002).

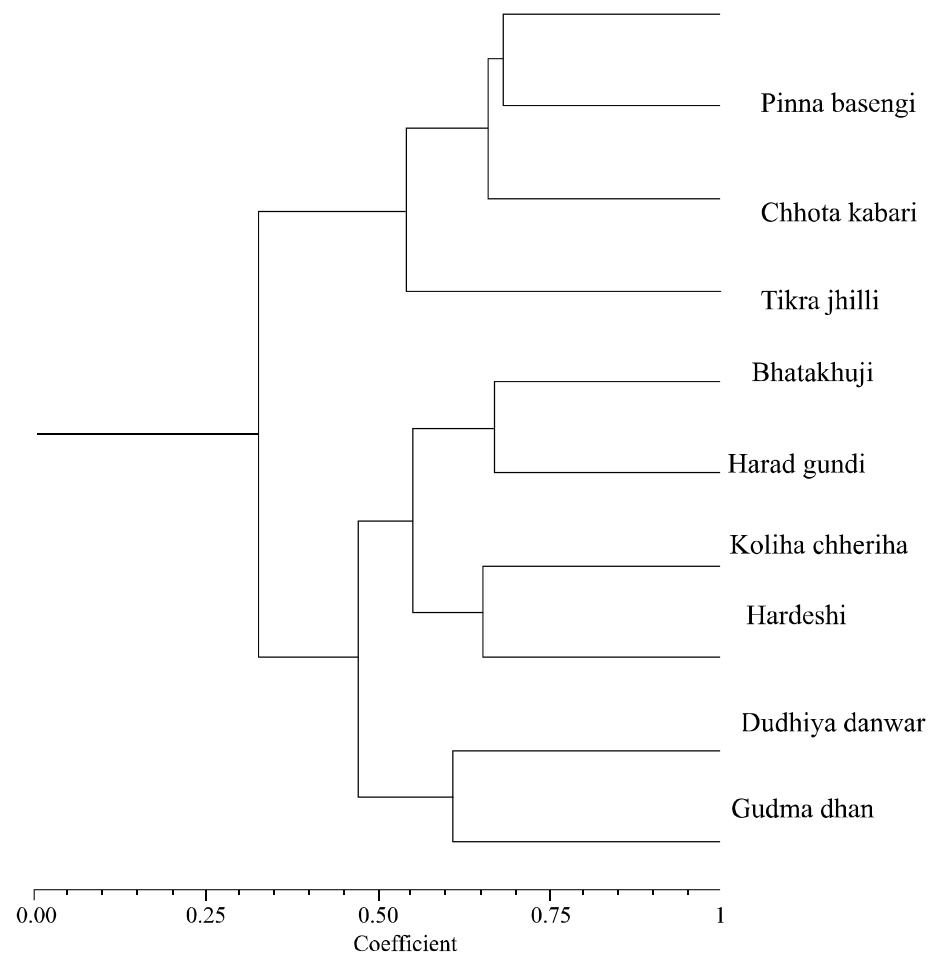

Fig 2.4. SSR based dendogram of rice landraces constructed using unpair group arthematic average (UPGMA) and similarity matrices computed according to Jaccard's coefficient.

\section{Conclusion}

The study was aimed at comprehensive analysis of nutritent content in milled grains of rice landraces. The study indicated significant variability for grain protein and essential amino acid content. The study clearly showed that the rice germplasm lines are quite different in their grain nutritive value. Five lines were identified for each of the highest endospermic protein and lysine concentration. Lines Harad Gundi, Koliha cheriha, Hardeshi, Dudhiya danwar, and Gudma dhan were found to possess $>9 \%$ grain protein. Similarly, Chhote sathaka, Pinna basengi, Chhota kabari, Tikrajhilli, and Bhata khuji had 6.30, 6.25, 7.13, 6.60, and $6.63 \mathrm{~g}$ per $16 \mathrm{~g} \mathrm{~N}$ grain lysine. Selected genotypes varying in endospermic protein content are genetically diverse, and could be potentially utilized in biofortification programmes. A number of polymorphic SSR markers revealed that a substantial variation existed in the rice accessions. DNA fingerprinting 
using SSR proved to be quite reliable and powerful in characterizing the rice genotypes. The estimated similarity ranged from $20.18 \%$ to $69.00 \%$ reflecting the rice landraces have much variation at the DNA level.

\section{Acknowledgement}

We are thankful to Department of Biotechnology (DBT), Govt. of India, for funding the project. Our sincere thanks to Indira Gandhi Agricultural University Rice Germplasm Section for sharing the material.

\section{References}

Banzinger, M. and J. Long. 2000. The potential for increasing the iron and zinc density of maize through plant - breeding. Food Nutr. Bull. 21: 3 97-400.

Chandel, G., M. S. Dudhare, T. Saluja, S. M. Shiva, Y. Sharma, A. K. Geda, G. R. Sahu, V. N. Mishra and S. K. Katiyar. 2005. Screening rice accessions for nutritional quality traits to achieve nutritionally balanced rice. In 5th International Rice Genetics Symposium, Nov. 19-23, 60-61.

Curn, V., J. Ovesna, L. Sakova and R. Sobotka. 2002. Identification of oilseed rape cultivars using AFLP markers. J. Cent. European Agri.: 285-291.

Dellaporta, S.L., J. Wood and J. B. Hicks. 1983. A plant DNA mini preparation version II. Plant Mol. Biol. Rep. 1: 19-21.

Jackson, M. T. and R. Juggan. 1993. Sharing the diversity of rice to feed the World. Diversity 9: 22-25.

Jam, R. K., P. Siwach, S. Jam, N. Saini and V. K. Choudhury. 2004. Allelic diversity among Basmati and non Basmati long-grain indica rice varieties using microsatellite markers. J. Plant Biochem. and Biotech. 13: 25-3 2.

Johri, R. P., S. P. Singh, K. N. Srivastava, H. O. Gupta and M. L. Lodha. 2000. Chemical and biological evaluation of nutritional quality of food grains: A laboratory manual. ICAR, New Delhi Publications.

Khush, G. S. 2002. The promise of biotechnology in addressing current nutritional problems in developing countries. Nutr. Bull. 23: 354-357.

Mahendra, S., C. Ravi, B. Viswanathan, A. Gulati and S. Ramchander. 2004. Economic liberalization, programs and household food security: A case study of India IFPRI. Markets, Trade and Industry (MTI) Discussion paper No.68.

Nagaraju, J., M. Kathirvel, R. R. Kumar, E. A. Siddiq and S. E. Hasnain. 2002. Genetic analysis of traditional and evolved Basmati and Non Basmati rice verities by using fluorescence based ISSR-PCR and SSR markers. PNAS. 999: 5836-5841.

Pellet, P.L. and Ghosh, S. 2004. Lysine Fortification: Past Present and Future. Food and Nutrition Bulletin 25: 2.

Riza, G., A. Ramos, R. V. Manaois, S. S. Escubio, G. D. Garcia, E. C. Arocena and L. S. Sebastian. 2004. Grain quality and iron density of Philippine rice cultivars. 4th International Crop Science Congress.pp.527-531.

Saker, M. M., S. S. Youssef, N. A. Abdallah, H. S. Bashandy and M. E. Sharkawy. 2005. Genetic analysis of some Egyptian rice genotypes using RAPD, SSR and AFLP. African J. Biotech. 49: 882-890. 